\title{
An incidental diagnosis of obturator hernia during total hip arthroplasty
}

\author{
Total kalça artroplastisi sırasında rastlantısal olarak saptanan obturator herni \\ Baran Sarıkaya, M.D., ${ }^{1}$ Baybars Ataoğlu, M.D., ${ }^{2}$ Erdinç Esen, M.D. ${ }^{2}$ \\ ${ }^{1}$ Department of Orthopedics and Traumatology, Kazan State Hospital, Ankara, Turkey \\ ${ }^{2}$ Department of Orthopedics and Traumatology, Medical Faculty of Gazi University, Ankara, Turkey
}

\begin{abstract}
Obturator hernia is a rarely seen disease that frequently affects females and the elderly population. It is clinically characterized with pain generally involving the hip region, and unless suspected, its diagnosis is difficult. Another reason for pain in the hip region and orthopedic surgery is coxarthrosis. The patient should be evaluated in detail radiographically and clinically before surgery. Although preoperative clinical examinations and radiographic findings support the indication for orthopedic surgery performed due to coxarthrosis, the probability of the presence of other pathologies accompanying the present disease should not be forgotten. In this article, we report an obturator hernia incidentally diagnosed in a 65 -year-old female patient who was performed total hip arthroplasty due to coxarthrosis.
\end{abstract}

Keywords: Obturator hernia; total hip arthroplasty; coxarthrosis.

Total hip arthroplasty is one the most successful surgical procedures in terms of the results of orthopedic surgery, which can be performed due to degenerative arthritis occurring in the joint following different etiological factors, and pain and functional impairment which may develop thereafter..$^{[1,2]}$ In this article, we report an obturator hernia incidentally diagnosed in a patient who has undergone total hip arthroplasty for coxarthrosis.

\section{CASE REPORT}

A 65-year-old female patient presented to our clinic with complaints of pain while walking and at rest, and movement impairment in the left hip. Total hip arthroplasty was performed on the patient whose degenerative arthritis was shown in direct radiography.
Obturator herni nadir görülen ve sıklıkla kadınları ve yaşlı nüfusu etkileyen bir hastalıktır. Klinik olarak genellikle kalça bölgesinde ağrıyla karakterizedir ve şüphe edilmedikçe tanısı zor konulur. Kalça ağrısı ve ortopedik cerrahi nedenlerinden birisi de koksartrozdur. Hasta cerrahi öncesi radyografik ve klinik olarak ayrıntılı şekilde değerlendirilmelidir. Ameliyat öncesi yapılan klinik muayeneler ve radyografik bulgular koksartroz nedeniyle uygulanan ortopedik ameliyat endikasyonunu desteklese de mevcut hastalığa eşlik edebilecek başka patolojilerin olabileceği unutulmamalıdır. Bu yazıda koksartroz nedeniyle total kalça artroplastisi uygulanan 65 yaşında bir kadın hastada rastlantısal olarak saptanan obturator herni sunuldu.

Anahtar sözcükler: Obturator herni; total kalça artroplastisi; koksartroz

The patient was placed in the supine position and an anterolateral approach was performed. After reaching the hip joint, the joint was dislocated and the femoral head was removed. The borders of the acetabulum were exposed. Before reamerization, it was observed that the soft tissue was herniated in the area of obturator foramen towards the acetabulum (Figure 1). It was thought that this structure, which had no relation to the surrounding muscles and soft tissue, might be a bowel loop herniating from the obturator foramen. The patient was referred to the general surgery department during the surgery, and it was confirmed that the present structure was a bowel loop herniating from the obturator foramen and that could be reduced. The surgery for the obturator hernia was delayed to a later session not to put the sterilization of the surgical procedure at risk, as well as the fact that

- Received: December 09, 2013 Accepted: January 20, 2014

- Correspondence: Baran Sarıkaya, M.D. Kazan Devlet Hastanesi Ortopedi ve Travmatoloji Kliniği, 06980 Kazan, Ankara, Turkey. Tel: +90 312 - 4827149 Fax: +90 312 - 8141425 e-mail: drbaran80@hotmail.com 
it requires another surgical incision. After reduction of the hernia from the obturator foramen, the surgical procedure was continued by placing the appropriate retractors around the acetabulum and the surgery was completed successfully.

\section{DISCUSSION}

Obturator hernias are pathologies formed in the obturator canal that are usually seen in the elderly and thin females, and develop in the region bordered by the superior ramus of the pubic bone anteriorly, obturator membrane, internal and external obturator muscles at the bottom, and obturator vessels and nerves, posterolaterally. Obturator hernia occurs through the obturator canal, which is $2-3 \mathrm{~cm}$ long and $1 \mathrm{~cm}$ wide, and contains the obturator nerve and vessels.

Obturator hernias are rarely observed, and clinical diagnosis is very difficult. They constitute $0.05-0.4 \%$ of all hernias ${ }^{[3]}$ and strangulated obturator hernia is present in $30 \%$ of cases. ${ }^{[4,5]}$ It is seen in females more frequently, as the obturator canal in females is larger inside the pelvis. ${ }^{[6]}$ Obturator hernia generally contains ileum and rarely colon, greater omentum, appendix, Meckel's diverticulum, urinary bladder, and gynaecological adnexa. ${ }^{[7]}$

Symptoms of obturator hernia are nonspecific. Usually obstruction develops clinically in patients who have not been diagnosed previously. As the disease is rarely seen, unless clinically suspected, its diagnosis is difficult. Most of the signs are due to compression of the obturator nerve by the hernia sac and its contents. Obturator hernias can cause paroxysmal hip pain, particularly prominent in the right side and its intensity increases during coughing, defecation, and micturition. Clinical complaints may include difficulty in walking and pain spreading towards the anterior surface of the hip joint and the internal surface of the thigh, particularly during extension, internal rotation, and abduction of hip (Howship-Romberg sign). The Howship-Romberg sign is present in 15 to $50 \%$ of obturator hernias. ${ }^{[3]}$ Pain intensity may decrease with hip flexion. ${ }^{[5,8]}$ Additionally, the Hannington-Kiff sign is more specific than the Howship-Romberg sign but less known. ${ }^{[3,9]}$ It refers to an absent adductor reflex in the thigh with an intact patellar tendon reflex in patients with obturator nerve compression.

Patient selection in total hip arthroplasty is quite important. Hip pain is detected as the most common complaint in $95 \%$ of the patients undergoing total hip arthroplasty. ${ }^{[10]}$ Every patient with hip pain should be evaluated extensively, and all pathologies which may cause hip pain should be considered. In our case, there were no faults in the surgical indication due to both the presence of radiographic signs of coxarthrosis and the overlap of the clinical condition with coxarthrosis. The detected obturator hernia during the surgery was thought to be incidental.

Many patients apply to orthopedic outpatient center with complaints of hip pain. Patients should
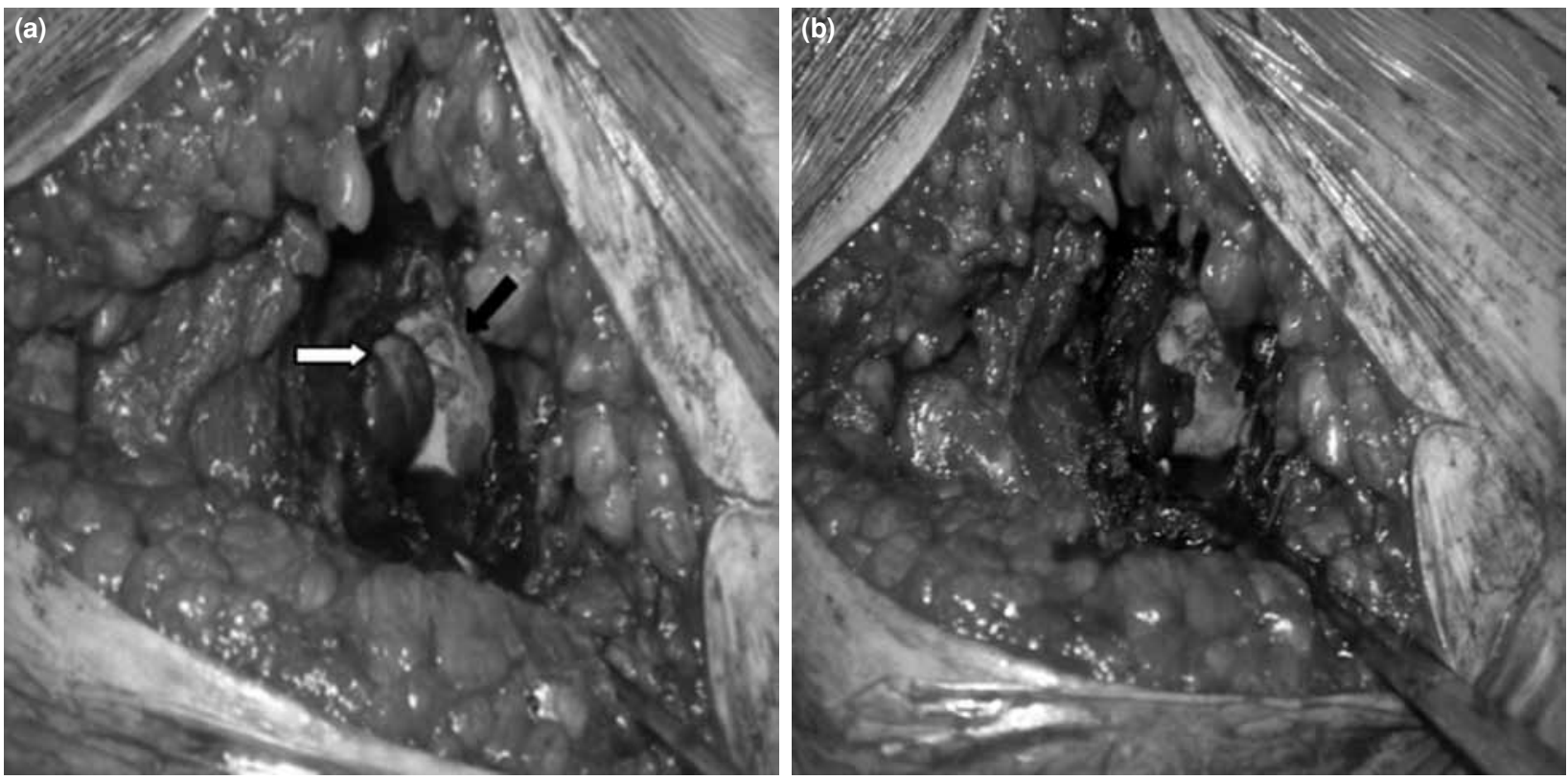

Figure 1. A bowel loop herniating from the obturator foramen to acetabulum. (a) Herniated bowel loop (white arrow), acetabulum (black arrow). (b) View of the acetabulum after reduction of the herniated bowel loop. 
be evaluated thoroughly and the likelihood of the presence of pathologies other than orthopedic pathologies which can cause pain in the same region should be kept in mind while a detailed physical examination should be completed before surgery.

\section{Declaration of conflicting interests}

The authors declared no conflicts of interest with respect to the authorship and/or publication of this article.

\section{Funding}

The authors received no financial support for the research and/or authorship of this article.

\section{REFERENCES}

1. Charnley J. Long-term results of low-friction arthroplasty. Hip 1982:42-9.

2. Sarıkaya B, Ataoğlu B, Görmeli G, Öztürk BY, Turanlı S. Eight-year follow-up of uncemented hydroxyapatite coated hip prosthesis for hip osteoarthritis secondary to developmental hip dysplasia. [Article in Turkish] Eklem Hastalik Cerrahisi 2013;24:91-5.

3. Ziegler DW, Rhoads JE Jr. Obturator hernia needs a laparotomy, not a diagnosis. Am J Surg 1995;170:67-8.

4. Bergstein JM, Condon RE. Obturator hernia: current diagnosis and treatment. Surgery 1996;119:133-6.

5. Guillem P, Bounoua F, Duval G. A case of hip pain in an elderly woman. Br J Radiol 2000;73:1233-4.

6. Shapiro K, Patel S, Choy C, Chaudry G, Khalil S, Ferzli G. Totally extraperitoneal repair of obturator hernia. Surg Endosc 2004;18:954-6.

7. Nakayama T, Kobayashi S, Shiraishi K, Nishiumi T, Mori S, Isobe K, et al. Diagnosis and treatment of obturator hernia. Keio J Med 2002;51:129-32.

8. Takada T, Ikusaka M, Ohira Y, Noda K, Tsukamoto T. Paroxysmal hip pain. Lancet 2011;377:1464.

9. Somell A, Ljungdahl I, Spangen L. Thigh neuralgia as a symptom of obturator hernia. Acta Chir Scand 1976;142:457-9.

10. Quintana JM, Aróstegui I, Azkarate J, Goenaga JI, Guisasola I, Alfageme A, et al. Evaluation by explicit criteria of the use of total hip joint replacement. Rheumatology (Oxford) 2000;39:1234-41. 